\title{
Sağlık Çalışanlarının Örgütsel Özdeşleşme, Örgütsel Bağlılık, Örgütsel Güven Ve Örgütsel Destek Algıları Arasındaki İlişkiler \\ (The Relationships Between Health Workers' Organizational Identification, Organizational Commitment, Organizational Trust and Perceived Organizational Support)
}

\section{Sabiha SEVINÇ ALTAŞ (iD) a}

a Sakarya Üniversitesi, Sağlık Hizmetleri Meslek Yüksekokulu, Tıbbi Hizmetler ve Teknikleri Bölümü, Sakarya, Türkiye. sabihas@sakarya.edu.tr

\begin{tabular}{|c|c|}
\hline MAKALE BİLGİSİ & ÖZET \\
\hline Anahtar Kelimeler: & $\begin{array}{l}\text { Amaç - Bu çalışmada sağlık çalışanlarının örgütsel özdeşleşme, örgütsel bağlılık, örgütsel güven ve } \\
\text { örgütsel destek algıları arasındaki ilişkilerin belirlenmesi amaçlanmaktadır. }\end{array}$ \\
\hline & a türündeki araştırmanın denek \\
\hline ven & eşleşme, \\
\hline Örgütsel Destek & $\begin{array}{l}\text { örgütsel bağlılık, örgütsel güven ve örgütsel destek ölçekleri kullanılmıştır. Çalışmada ilk olarak } \\
\text { güvenirlik ve geçerlilik analizleri yapılmıştır. Söz konusu bağımlı ve bağımsız değişkenler arasındaki }\end{array}$ \\
\hline $\begin{array}{l}\text { Gönderilme Tarihi } 2 \\
\text { Şubat } 2021\end{array}$ & $\begin{array}{l}\text { ilişkileri ortaya koyabilmek, ayrıca hipotezleri test edebilmek için korelasyon ve regresyon analizleri } \\
\text { gerçekleştirilmiştir. }\end{array}$ \\
\hline $\begin{array}{l}\text { Revizyon Tarihi } 15 \text { Mart } \\
2021\end{array}$ & $\begin{array}{l}\text { Bulgular - Yapılan korelasyon analizi ile örgütsel özdeşleşme, örgütsel bağlllık, örgütsel güven ve } \\
\text { örgütsel destek algıları arasında pozitif yönde anlamlı ilişkiler bulunmuştur. Regresyon analizi sonuçları }\end{array}$ \\
\hline Kabul Tarihi 25 Mart 2021 & $\begin{array}{l}\text { örgütsel desteğin, örgütsel güven, örgütsel bağlllık ve örgütsel özdeşleşmeyi pozitif yönde etkilediğini } \\
\text { göstermektedir. Örgütsel güven algısı örgütsel özdeşleşmeyi ve örgütsel bağlllı̆̆1 pozitif yönde } \\
\text { etkilemektedir. Ayrıca örgütsel özdeşleşme, örgütsel bağlllığı pozitif yönde etkilemektedir. }\end{array}$ \\
\hline $\begin{array}{l}\text { Makale Kategorisi: } \\
\text { Araştırma Makalesi }\end{array}$ & $\begin{array}{l}\text { Tartışma - Elde edilen bulgular literatürdeki bulguları destekler niteliktedir. Örgütlerin başarıyı } \\
\text { yakalamasında en önemli faktör olan insan kaynağının desteklenmesi, örgüte ve yöneticiye güven } \\
\text { ortamının yaratılması çok önemlidir. Gelecekteki çalışmalar için farklı kültürlerde, farklı sektörlerde aynı } \\
\text { değişkenlerin incelenmesi ve sağlık çalışanlarında kamu, özel karşılaştırılması önerilmektedir. }\end{array}$ \\
\hline
\end{tabular}

\section{ARTICLE INFO}

\section{Keywords:}

Organizational

Identification

Organizational

Commitment

Organizational Trust

Perceived Organizational

Support

Received 2 February 2021

Revised 15 March 2021

Accepted 25 March 2021

Article Classification: Research Article

\section{ABSTRACT}

Purpose - In this study, it's aimed to determine the relationship between health workers' organizational identification, organizational commitment, organizational trust and perceived organizational support.

Design/methodology/approach - The study is of descriptive nature and participants are comprised of health workers in Kocaeli province. Organizational identification, organizational commitment, organizational trust and organizational support scales were used in the questionnaire form to collect data. Firstly, the validity and reliability of the measurement instrument are tested. Correlation and series of regression analyses are applied for investigating relationships and testing research hypotheses.

Findings -By correlation analysis, positive significant relationships were found between organizational identification, organizational commitment, organizational trust and organizational support perceptions. Regression analysis results show that organizational support positively affects organizational trust, organizational commitment and organizational identification. Organizational trust perception positively affects organizational identification and organizational commitment. In addition, organizational identification positively affects organizational commitment.

Discussion - The findings that is obtained support the findings in the literature. It is very important to support human resources, which is the most important factor for organizations to achieve success, and to create an environment of trust in the organization and the manager. For future studies, it is recommended to examine the same variables in different cultures and different sectors and to compare public and private in healthcare professionals. 


\section{GİRIŞ}

İnsanları verimli çalışmaya sevk eden en kritik unsurlardan birisi yöneticinin tutum ve davranışlarıdır. Örgütlerin çalışanlarına karşı bakış açısı, çalışanların örgütlerine ve işlerinde karşı tutum ve davranışlarını etkilemektedir. Son yıllarda örgütsel destek konusunda yapılan çalışmalarda artış görülmektedir. Örgütsel destek algısının, işgörenlerin örgüte bağlılığını yükselttiği ve örgütsel hedeflere ulaşmada şartları zorlayarak yüksek çaba gösteren çalışanların beklentilerinin karşılanacağı varsayılmaktadır. Örgütsel destek algısı güçlü olan işgörenler teorik olarak örgütlerine katkı sağlayacak davranışlar göstermeye meyillidir (Eisenberger vd. 1986: 500-501). Bu doğrultuda örgütsel bağlllık, örgütsel özdeşleşme, örgütsel güven, örgütsel vatandaşlık davranışı, iş performansı, iş tatmini, işten ayrılma eğilimi gibi çıktılarla ilişkili olduğunu gösteren araştırmalar literatürde yer almaktadır (Settoon vd.,1996; Shore ve Wayne,1993; Moorman vd.,1998; Rhoades ve Eisenberger, 2002; Turunç, Çelik,2010; Naktiyok, İşcan, 2019). Bu doğrultuda örgütsel destek, işgören ve örgüt açısından olumlu sonuçların oluşmasını sağlayacak bir değişken olarak ifade edilebilmektedir.

Chen ve arkadaşları (2015:3), sosyal kimlik kuramı kapsamında ele aldıkları örgütsel özdeşleşmeyi; “bireylerin kendilerini özel bir grubun üyesi olarak gördükleri özel bir sosyal kimlik biçimi" olarak tanımlamışlardır. Örgütsel özdeşleşme sıklıkla örgütsel bağlılıkla karıştırılmaktadır. Örgütsel bağlılıkta örgütsel değerleri, inançları "kabullenme" vardır. Örgütsel özdeşleşme ile bu değer ve inançları kabullenmenin ötesine geçilerek "sahiplenme" ve "paylaşmanın" söz konusu olduğu belirtilmektedir (Epitropaki \& Martin 2005:571). İşgören ve örgüt için önemli katkılar sağlayacak değişkenler olarak kabul edilmektedir.

İşletmelerde örgütün temelini güvenin oluşturduğu ifade edilmektedir. Örgütsel güven doğruluk, dürüstlük, tutarlılık, açılık gibi kavramlardan beslenmektedir (Demirkaya ve Kandemir, 2014:268). Mayer ve arkadaşları (1995:712) güveni; "karşı tarafın niyetine ve davranışlarına ilişkin olumlu beklentileri esas alan savunmasız kalma eğilimi" şeklinde tanımlamaktadır. Örgütte güven ortamı; motivasyonu ve iş performansını arttırır, ilişkileri geliştirir, yöneticilerin etkinliğini yükseltir.

Bu doğrultuda araştırmanın amacı, örgütsel özdeşleşme, örgütsel bağlllık, örgütsel güven ve örgütsel destek değişkenleri ilişkisini sağlık çalışanları örneklemi ile incelemektir. İlk olarak, örgütsel özdeşleşme, örgütsel bağlllık, örgütsel güven ve örgütsel destek kavramlarına ilişkin bilgiler verilmiştir. Değişkenlerin birbiri ile ilişkilerine dair ilgili yazındaki araştırmalar ortaya koyulmuştur. Çalışmanın metodolojisi ve uygulanan analizler kapsamlı bir şekilde açıklanarak bulgular ortaya konmuştur. Son olarak, söz konusu değişkenler arasındaki ilişkiler belirtilerek, ilgili yazına ilişkin tartışmalara ve ileriye dönük perspektiflere yer verilmiştir.

\section{KAVRAMSAL ÇERÇEVE}

\section{1. Örgütsel Özdeşleşme}

Örgütsel davranış yazınında, örgütsel özdeşleşme kavramı uzun bir süredir bireyin memnuniyeti ve örgütün etkinliği üzerinde aktif rol oynayan bir yapı olarak dikkat çekmektedir. Örgütsel özdeşleşme hem teorik hem deneysel olarak çalışılmıştır. Örgüte bağlllık, benimseme, etkilenme ve özdeşleşmenin öncülleri ve sonuçlarıyla daha doğrusal ilişkisi görülen örgütsel davranışlar ve benzeri yapılarla sık sık karıştırılmaktadır (Ashforth, Mael, 1989: 20).

Örgütsel özdeşleşme, örgüt ve işgörenler arasındaki psikolojik ilişkiyi yansıtmaktadır. Aynı zamanda iş hayatındaki birçok önemli tutum ve davranışı açıklamaktadır (Edwards, 2005: 207). İşgörenlerde bireysel ve örgütsel değerlerin örtüşmesi ile birliktelik ve aidiyet algısının oluşması veya kişinin kendini tanımlamada özellikli bir örgütün üyesi gibi algıladığı süreçtir (Riketta, 2005:360).

Özdeşleşme çalışanın kendini örgütle bir, örgüte ait hissetmesi, örgütün başarı veya başarısızlığını kendi başarı ve başarısızlığı gibi hissetmesi olarak tanımlanmaktadır (Mael ve Ashforth, 1992:103). Özdeşleşme, bir işgörenin kendisini daha büyük bir bütünün (çalışma grubu, firma, kilise vb) parçası olarak algıladığı psikolojik bir durumdur (Rousseau, 1998: 217).

Örgütsel özdeşleşme, örgütün hedefleriyle bireyin kendisini bağdaştırmasıdır (Edwards, 2005: 208). Bir örgütteki çalışanın örgütsel özdeşleşme seviyesi, benliğinin o örgüt üyeliğine ne kadar bağlı olduğunu göstermektedir. Eğer bu üyelik benliğinin merkezinde yer alıyorsa, başka sosyal grup üyeliklerinden daha önemli bir yerde ise birey için yüksek düzeyde özdeşleşme oluşmuş demektir (Karabey ve İşcan, 2007:232). Çalışanların örgütlerinde özdeşleşme düzeyleri farklı olabilmektedir. Bir örgütün üyesi olarak; 
a.Bir çalışanın örgüt üyesi kimlik algısı alternatiflerden daha belirginse,

b.Sosyal bir grup olarak örgütün özellikleri ile kendini tanımladığı özellikler çok benzer ise, kişi örgütle özdeşleşmiş demektir(Dutton vd., 1994: 239).

İlgili yazında örgütsel bağlılık ve örgütsel özdeşleşme benzerliği tartışılmış bir konudur. Ashforth ve Mael (1989:23), örgütsel özdeşleşmeyi örgüte özel bir kavram olarak ifade etmektedir. Oysa bağlllı̆̆ın tanımlanması örgüte özgü olsa da kendisi değildir. Mael ve Ashforth'a (1992:105) göre özdeşleşme kişisel görüşün bir parçasıdır. Kendinden tanımlı bir kavramken örgütsel bağlılık böyle değildir. Özdeşleşme işgören açısından "ben kimim?" sorusunun cevabını verir. Aynı zamanda işgörenin kendisi ve örgüt değerleri ile tanımlamasına yardımcı olur. Kısacası örgütsel özdeşleşme, örgütle dayanışma duygusu içinde olmayı, örgüte destekte bulunmayı ve de örgüt tarafından paylaşılan ayırt edici özelliklerin algılanmasından oluşmaktadır (Miller vd., 2000: 629).

\section{2.Örgütsel Bağlılık}

Whyte (1956) tarafından literatüre giren örgütsel bağlllık kavramı, kısa sürede üzerinde yoğun olarak çalışılan bir konu olmuştur (Candan ve İnce, 2016: 234). Örgütsel bağlllık, “Bir bireyin örgüte işle ilgili katılım, sadakat ve kurumun değerlerine olan psikolojik bağları" olarak tanımlanmaktadır (O'Reilly ,1989:18). Porter ve arkadaşlarının üç özelliği bulunan tanımı da genel kabul görmüş bir tanımdır.

-Örgütün amaç ve değerlerine duyulan güçlü inanç,

-Örgüt amaçlarının başarılması için çabalama,

- Örgüt üyeliğinin kalıcı olmasına yönelik kuvvetli arzudur (Porter vd., 1974: 656).

Meyer \& Allen (1984) tarafından geliştirilen çok boyutlu örgütsel bağlılık modeli en çok çalışılan modeldir. Model ilk başlarda iki boyutlu olarak tasarlanmıştır. Duygusal ve zorunlu bağlılık boyutlarından oluşan modele normatif bağlllı eklenerek üç boyutlu hale getirilmiştir. Meyer ve Allen'in çok boyutlu örgütsel bağllılı modeli ile işgörenlerin örgütlerine olan bağl1lı̆̆ının duygusal, normatif ve zorunlu olmak üzere farklı, ayırt edilebilir üç unsura sahip olduğu ifade edilmektedir (Meyer vd., 2002: 20-21).

Allen \& Meyer'in (1990)'ın geliştirdiği örgütsel bağlılık modelinin birinci unsuru duygusal bağlllıktır. Duygusal bağlılık işgörenlerin örgütlerine karşı duygusal ilgileri ile ilgilidir. Örgüte katılma, ait olma ve örgütsel özdeşleşme arzusu olarak tanımlanmaktadır. Zorunlu bağlllık, işgörenin işini kaybetmesi durumunda karşı karşıya kalacağı maddi boyut algısından oluşan bu sebeple örgüte devam bağlılığıdır. Zorunlu bağlılıkta çıkar, kazanç ve mübadele esasları ile ilgilidir. Zorunlu bağlllığın oluşmasında temel faktör örgütten ayrılmanın maddi boyutunun yüksekliğidir. İş görenler bu riski çoğu zaman almak istemezler. Örgütsel bağlllığın üçüncü boyutu olan normatif bağlllıkta değerler, inançlar vb. faktörler önemli rol oynamaktadır. Ahlaki değerler ve inançlar gereği örgütte kalmak ahlaki bir zorunluluk olarak algılanmaktadır (Meyer vd., 1998: 42).

\section{3.Örgütsel Güven}

Örgütsel güven bireylerin belirsizlik ve riskli bir durumla karşılaştıklarında, örgütün yardımcı olmada kendilerine verdikleri söz ve davranışları ile tutarlı olup olmaması yönündeki inançlarıdır (Matthai, 1989:52). Zaheer vd.'e(1998) göre güven, zorlukların aşılacağına, söylenen şekilde davranılacağına, faydacı durumlarda adaletli olunacağına ilişkin beklentidir (Tüzün, 2007:98).

Örgütsel güven, üst yönetimin işgörenlere desteği, iş yaşamında adaletin sağlanması, çalışanların gereksinimlerinin karşılanması, işgörenler arası iş birliğinin geliştirilmesi, kurum içindeki sosyal ilişkilerin istenilen seviyeye çıkarılması konusunda önem taşımaktadır (Neves ve Caetano, 2006:355). Mishra'ya göre (1996: 5) güven; örgütte bir tarafın diğer tarafa yeterli, açık, ilgili, itimat edilebilir olduğuna yönelik inancı sebebiyle savunmasız kalma arzusudur.

Literatürde örgütsel güven, genellikle yöneticiye güven ve örgüte güven olmak üzere iki alt boyutta ele alınmaktadır (Nyhan ve Marlowe, 1997: 624). Mishra ve Morrissey (1990)'e göre örgütsel güven, bir işgörenin örgütünün sağlayacağı desteğe yönelik algısı, liderinin doğru söyleyeceğine ve sözünün arkasında duracağına 
ilişkin inancıdır. Böylece güven yatay ve dikey olarak örgüt içi iletişimin temelini oluşturmaktadır (Demircan, Ceylan, 2003:142). Yöneticinin işgörenlerle güven ilişkisini başarabilmesi için tutarlı ve saygın davranış sergilemesi, denetimi paylaşması ve dağıtması, etkili iletişim kurması ve ilgi göstermesi gerekmektedir (Büte, 2011: 176). Çalışanlar bazen bu iki güven türünü karıştırabilmektedir. Yöneticilerine güvendiklerinde onu örgütün bir temsilcisi olarak algıladıklarından bu güveni örgütün tamamına atfedebilirler. Çalışanların güvenini kazanmak isteyen yöneticiler bütünlük içinde ve tutarlı olmalıdır. Tutarlılık yönetici davranışlarının geçmişini esas almakta ve tahmin edilebilirlikleri yansıtmaktadır. Bütünlük yöneticinin davranışları ve sözleri arasındaki uyumla ilgilidir (Tokgöz, Seymen,2013:63). Çalışanların örgüte ve yöneticisine güveninin farklı sonuçları bulunmaktadır. Örgüte güven, örgütsel bağlılı̆̆ı arttırarak işgören devir hızını etkilemektedir. Yöneticiye güven ise işgören memnuniyeti ve yenilikçi davranış sergilemeyi etkilemektedir (Tan, Tan,2000:241).

\section{4.Örgütsel Destek}

Rekabetin son derece acımasız olduğu günümüzde "insan" faktörü başarının anahtarı olmaya devam etmektedir. Özcaner(2003) insanın önemini şu şekilde açıklamaktadır. "Bir işgörenin zamanını, fizik gücünü satın alabilirsiniz. Uzmanlığından belli bir zaman diliminde yararlanabilirsiniz. Fakat onun işine duyduğu düşkünlüğü, inisiyatifi ve içinden gelen özveri satın alınamaz. Bu sadece kazanılabilir" (Dinç, Birincioğlu,2020:313). Bu doğrultuda işgörenlere değer verilmesi ve desteklenmesi gerekmektedir. House(1981) desteği, farklı kaynaklardan gelen faydalı katkı, taktir, duygu ve bilginin algılanan akışı olarak tanımlamaktadır ((Parasuraman vd., 1992:344). Çalışanlar iş ortamında destek beklentisi içindedir. Saygı duyulma, onaylama, duygusal destek ihtiyacının karşılanmasında örgütsel destek önemli bir kaynaktır.

Örgüt, işgörenlerin örgüte katkılarının farkında olarak, mutluluklarına önem vererek, birlikte çalışmaktan memnuniyetini belirterek, ait olma, saygı ve onaylama ihtiyacını karşılayarak örgütsel destek sunmaktadır (Armeli vd.,1998:299). Eisenberger ve arkadaşlarının (1986,500) örgütsel destek algısı tanımı literatürde büyük ölçüde kabul görmüştür. Örgütsel destek, örgütün işgöreninin katkısına değer vermesi, mutluluğunun önemsendiğine dair algıları ile işgörenlerin etkilendiği politika, kural ve faaliyetlerin gönüllülük esasına göre gerçekleştirildiğine ilişkin duygulardır. Örgütün çalışanının katkısına ve refahına verdiği değere yönelik inançtır (Rhoades vd., 2001,825). Örgütsel destek algıs1, işgörenlerin kendisine verilen değer ve önemsenme konusundaki fikridir (Eisenberger vd.,1990).

Algılanan örgütsel destek, örgütün çalışanlarına bağlı olduğu, onlara değer verdiğiı, bu da çalışanların örgütlerine ilişkin bağlılığı arttırması olarak ifade edilmektedir. Dolayısıyla algılanan örgütsel destek, çalışanların örgütleriyle olan sosyal ve ekonomik değişim ilişkilerinin gücü, karşılıklı yükümlülük algıları ve bu yükümlülüklerin yerine getirilmesi gibi diğer sosyal etkileşim değişkenleriyle ilgili olmalıdır (Gakoviç ve Tetrick, 2003:649-650).

Örgütsel destek algısı, işgörenlerin sosyo-duygusal ihtiyaçlarının karşılanmasında faydalı olmaktadır. İşgörenin işinde çabasının artması halinde örgütün ödüllendirmeye hazır olduğunu göstermektedir. Aynı zamanda örgütün işini etkili bir şekilde yerine getirmek için gerektiğinde yardım sağlama eğilimini göstermektedir (Asalage ve Eisenberger, 2003, 493). Örgütsel destek algısı, kendini geliştirmek ve başarılı olmak isteyen bir çalışana gerekli olan kaynakları sağlamada istek uyandırabilmektedir (Çakar, Yıldız, 2009:77).

Teoriye göre örgütsel destek algısı üç aşamalı bir süreçten oluşmaktadır. Birincisi, çalışanlar örgütün refahını önemsemelidir. Örgütün belirlediği hedeflere ulaşılabilmesi için bir zorunluluk hissi yaratılmalıdır. İkincisi, algılanan örgütsel destek, çalışanların önemsenme, kabul ve saygı görme ihtiyaçlarını karşılamaktadır. Böylece, çalışanların örgüt üyeliği ve statülerinin sosyal kimlikleri ile örtüşmesi sağlanmalıdır. Üçüncüsü ise, çalışanlarda performans artışının örgüt tarafından önemsenmesi ve ödüllendirmesi yönündeki inanc1 güçlendirmelidir. Bu süreçteki tüm adımlar hem çalışan (iş tatmininin artması ve olumlu ruh hali) hem de örgüte (duygusal bağlılığın artması, işgücü devrinin azalması) fayda sağlamaktadır (Rhoades ve Eisenberger, 2002, 699).

Özdevecioğlu (2003, 117-118) destekleyici örgütün özelliklerini beş maddede açılamaktadır:

1. Örgüt çalışanlarının yaratıı fikirleri, önerilerini ve eleştirileri önemsenerek, uygulamaya aktarılmalıdır. 


\section{S. Sevinç Altaş 13/1 (2021) 875-891}

2. Çalışanlara iş güvenliği sağlanmalı, devamlı çalışacaklarına ilişkin güvence verilmeli, işini kaybetme korkusu ortadan kaldırılmalıdır.

3.İş ortamında pozitif insan ilişkileri oluşturulmalıdır. Örgüt içi iletişim ve halkla ilişkiler arttırılmalıdır.

4.Kayırmaca yapılmamalı, hak yenmemeli ve örgütsel adalet sağlanmalıdır.

5.Çalışanlar önemsenmeli ve kararlara katılımları sağlanmalıdır. Tüm bunlar çalışanlar tarafından örgütsel destek olarak algilanacaktır.

\section{5. Örgütsel Özdeşleşme, Örgütsel Bağlılık, Örgütsel Güven ve Örgütsel Destek Algısı Arasındaki İlişkiler}

Örgütsel destek algısının önemli sonuçlarından biri örgütsel bağlılıktır. Çalışanlar kurum faaliyetlerinin kendileri içim yararlı olmasına yüksek düzeyde bağlılık ve performans ile karşılık verirler (Rhoades ve Eisenberger, 2002, 699). Çalışanların örgütüne yönelik oluşan destek algısı örgütsel bağlılığın oluşmasını sağlamaktadır. Örgütsel destek algısı ve örgütsel bağlılık boyutları ile ilgili birçok çalışma bulunmaktadır (Eisenberger vd., 1986; Eisenberger vd., 1990; Rhodas vd. 2001; Eisenberger vd., 2002; Yoon ve Thye, 2002; Özdevecioğlu, 2003; Aube vd.2007; Tumwesigye, 2010; Kaplan, Öğüt,2012; Kim vd.2016; Özgül vd.,2020; Dinç, Birincioğlu,2020). Sonuçlar ise genellikle, algılanan örgütsel destek ile duygusal ve normatif bağlllık arasında pozitif yönlü ilişki olduğu şeklindedir. Devam bağlllığı ile negatif yönlü ilişki bulgusu da görülmüştür. İlgili yazında yapılan araştırmalar göz önünde bulundurularak aşağıdaki hipotez geliştirilmiştir:

H1. Örgütsel destek algısı işgörenlerin örgütsel bağlılığını olumlu yönde etkiler.

Algılanan örgütsel destek, zor durumlarda örgütün işgörenine yardımcı olacağının bir tür garantisidir. Çalışanlarının katkılarına değer verme, onların iyiliğini isteme bunun göstergesidir. İş ilişkilerinin etkili bir şekilde sürmesi için güvenin örgütlerde karşılıklı bir şekilde bulunması çok önemlidir (İşcan ve Sayın, 2010: 196). Çalıştığ1 örgütten destek algilayan bireylerin örgütlerine yönelik güvenleri de artmaktadır (Chen vd., 2003; DeConinck, 2010; Taşdan, Yalçın,2010; Paille', Bourdeau,2010; Kurtessis vd. 2017; Narang, Singh 2012; Özdevecioğlu, 2003; Naktiyok, İşcan, 2019). İlgili yazında yapılan araştırmalar göz önünde bulundurularak aşağıdaki hipotezler geliştirilmiştir:

H2. İşgörenlerin örgütsel destek algısı yöneticiye olan güveni olumlu yönde etkiler.

H3. İşgörenlerin örgütsel destek algısı örgüte olan güveni olumlu yönde etkiler.

Çalışanların örgütsel özdeşleşme düzeyini artırdığı düşünülen kavramlardan birisinin çalışanların algıladıkları örgütsel destek olduğu düşünülmektedir. Örgütsel destek algısı yüksek çalışanlarda, örgütle özdeşleşmenin de arttığı görülmektedir (Cheung, Law ,2008; Turunç, Çelik,2010; Nartgün, Kalay,2014; İplik vd.,2014; Sökmen vd., 2015; Kerse, Karabey,2017; Uzun,2018; Demir,2020). İlgili yazında yapılan araştırmalar göz önünde bulundurularak aşağıdaki hipotez geliştirilmiştir:

H4.İsgörenlerin örgütsel destek algısı örgütsel özdeşleşmeyi olumlu yönde etkiler.

Çalışanların örgütsel güvenlerinin artmasının sonuçlarından biri de örgütsel özdeşleşmedir (Tokgöz, Seymen,2013:65). Karşılıklı güven en yüksek seviyede oluştuğunda, önceliklere önem verildiği varsayılarak örgütsel özdeşleşme meydana gelmektedir (Edwards, Cable, 2009; Öktem vd.,2016; Tokgöz, Seymen,2013; Khattak vd.,2014; Champell, Im, 2015; Biçkes, Yılmaz, 2017; Kabadayı,Türkay, 2020; Çankaya,2020). İlgili yazında yapılan araştırmalar göz önünde bulundurularak aşağıdaki hipotezler geliştirilmiştir:

H5. İşgörenlerin yöneticiye güveni örgütsel özdeşleşmeyi olumlu yönde etkiler.

H6. İşgörenlerin örgüte güveni örgütsel özdeşleşmeyi olumlu yönde etkiler.

Örgütler işgörenlerinin güven düzeylerini arttırmanın yollarını aramalıdır. Böylece yüksek düzeyde güven duygusu hisseden bireylerin örgüte bağllıkları da artacaktır. İlgili yazında örgütsel güven ve örgütsel bağlılık boyutlarının araştırıldığı birçok çalışma mevcuttur ((Taşkın ve Dilek, 2010; Demirel, 2008; Chughtai vd., 2006; Çubukçu ve Tarakçıŏlu, 2010; Cho vd., 2011; Özgan, 2011; Eğriboyun, 2015; Akkaya,2020). İlgili yazında yapılan araştırmalar göz önünde bulundurularak aşağıdaki hipotezler geliştirilmiştir:

H7. İşgörenlerin yöneticiye güveni örgütsel bağlılığı olumlu yönde etkiler. 
H8. İşgörenlerin örgüte güveni örgütsel bağl1lığı olumlu yönde etkiler.

Örgütsel bağlılık ve özdeşleşme, araştırmacılarının çalışan-örgüt ilişkisini incelemek için kullandıkları iki yapıdır. İlgili yazında örgütsel özdeşleşme ve örgütsel bağlılık boyutlarının araştırıldığı birçok çalışma mevcuttur (Sass, Canary,1991; Tyler,Blader,2001; Loi vd.,2004; Bedeian,2007; Çakınberk vd.,2011; Polat, Meydan,2011; Sökmen,Bıyık 2016; Sökmen,2019). İlgili yazında yapılan araştırmalar göz önünde bulundurularak aşağıdaki hipotez geliştirilmiştir:

H9. İşgörenlerde örgütsel özdeşleşme örgütsel bağlllı̆̆ı olumlu yönde etkiler.

\section{YÖNTEM}

\subsection{Araştırmanın Modelleri}

Bu araştırmada ilişkisel tarama modeli kullanılmıştır. Karasar(2011)' e göre ilişkisel tarama modeli değişkenler arasındaki birlikte değişimin mevcudiyetini belirlemektedir. Değişkenler birlikte değişiyormu, değişim mevcutsa nasıl gerçekleştiği saptanmaya çalışılmaktadır. Croswell (2000) bu tarama modelini, tek ya da birden fazla bağımsız ve bağımlı değişken arasındaki ilişkinin belirlenmesi olarak açıklamaktadır (Keleş,Koç, 2020:37). Bu araştırma Kocaeli'deki kamu hastane çalışanlarının örgütsel özdeşleşme, örgütsel bağlllık, örgütsel güven ve örgütsel destek algısı arasındaki ilişkileri belirlemek amacıyla yapılmıştır. Bahsi geçen değişkenlerin arasındaki ilişkiyi araştıran yerli ve yabancı yayınların incelenmesi neticesinde hipotezler ile araştırma modeli (Şekil 1) oluşturulmuştur.

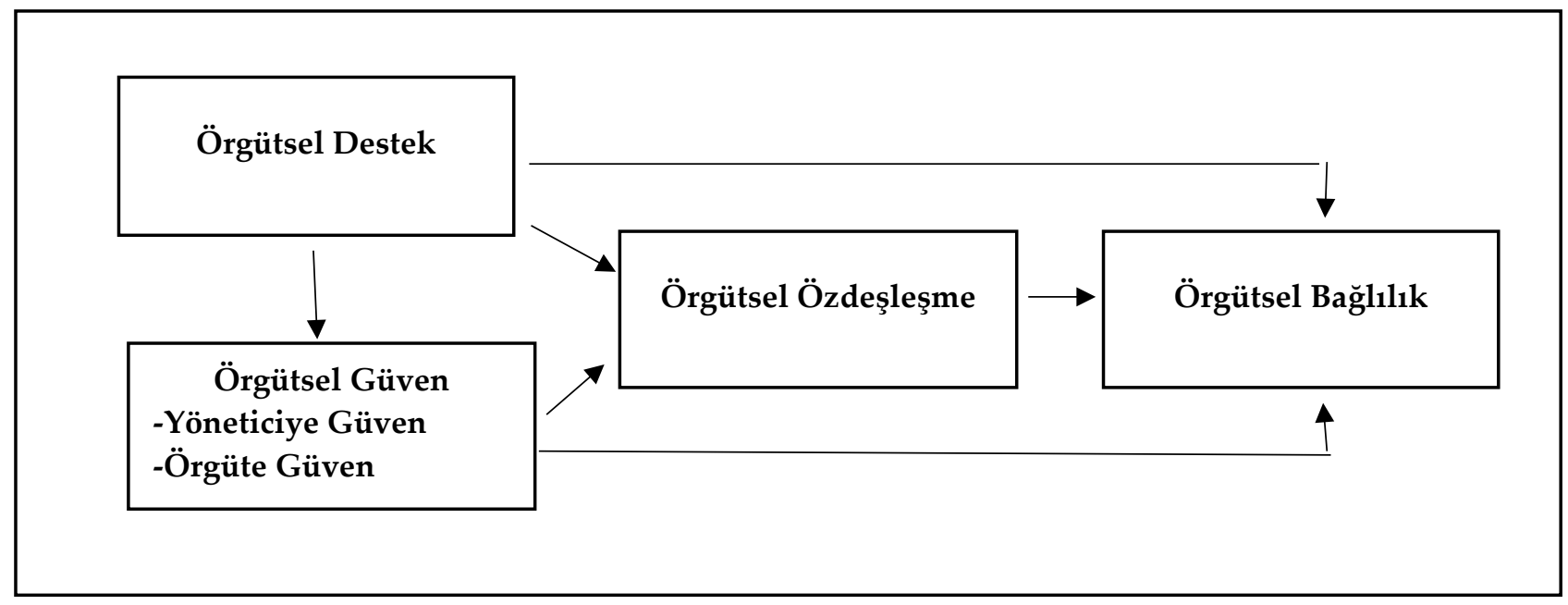

Şekil 1.Araştırma Modeli

\subsection{Evren ve Örneklem}

Araştırmanın anakütlesini Kocaeli ili kamu hastaneleri çalışanları oluşturmaktadır. 20 Ocak verilerine göre, Kocaeli ili ve ilçelerindeki kamu sağlık kuruluşlarında 8308 sağlık çalışanı görev yapmaktadır (Sağlık Bakanlığı,2021). Örneklem grubu kolayda örnekleme ile oluşturulmuştur. Vogt (2012) vd.'ne göre, araştırmacılar örneklem hacminin genelleme yapmaya imkan tanımadığını düşündükleri durumlarda kullanılmaktadır (Baltacı,2018:259). Farklı bölümlerde görev yapan 219 sağlık çalışanı örneklemi oluşturmaktadır. Araştırmanın önemi çalışanlara yüz yüze anlatılarak anketi doldurmaları istenmiştir. Araştırma verilerinin toplanması 2020 Eylül ayında gerçekleştirilmiştir.

\subsection{Verilerin Toplanması}

Kocaeli kamu hastanesi çalışanlarının algıladıkları örgütsel özdeşleşme, örgütsel bağlılık, örgütsel güven ve örgütsel destek arasındaki ilişkileri ortaya koyabilmek maksadıyla anket tekniği kullanılarak verilere ulaşılmıştır. Veriler 2020 yılı Eylül ayı Covid-19 pandemi döneminde sağlık çalışanlarından elde edilmiştir. Hazırlanan anket formu beş bölümden oluşmaktadır. İlk bölüm; çalışanların demografik özelliklerinin belirlendiği sorulardan oluşmaktadır. Anketin ikinci bölümünde; örgütsel destek algısı değişkeninin ölçümünde Eisenberger vd. (1986) tarafından geliştirilen toplam 36 sorudan oluşan Örgütsel Destek Algisı Ölçeğinin, daha önce Eisenberger vd. (2001) ve Shanock ve Eisenberger (2006) tarafından kullanılmış olan 8 
soruluk kısa versiyonu kullanılmıştır. Anketin üçüncü bölümünde; sağlık çalışanlarının örgütsel güven tutumlarını belirlemek amacıyla 12 sorudan oluşan, Nyhan ve Marlowe (1997) tarafından oluşturulmuş örgüte güven ve yöneticiye güven olmak üzere iki boyuttan oluşan ölçek kullanılmıştır. 12 sorunun 8'i yöneticiye güveni, 4 soru örgüte güveni ölçmektedir. Anketin dördüncü bölümündeki örgütsel bağlılık soruları, Babin and Boles (1998), Netemeyer et al. (1997) ve Hartline and Ferrell (1996)'ın makalelerinden uyarlanmıştır ve dört sorudan oluşmaktadır (Toklu, 2016:58). Anketin son bölümündeki örgütsel özdeşleşme ölçeği altı sorudan oluşmakta ve ölçek Mael ve Ashforth (1992) tarafından geliştirilmiştir. Anket soruları beşli Likert ölçeği ile derecelendirilerek ölçülmüştür. (1) Kesinlikle Katılmıyorum (2) Katılmıyorum (3) Ne Katılıyorum Ne Katılmıyorum (Kararsızım) (4) Katılıyorum (5) Kesinlikle Katılıyorum şeklinde derecelendirilmiştir.

\subsection{Verilerin Analizi}

Kocaeli ili kamu hastaneleri çalışanlarının algıladıkları örgütsel destek, örgütsel güven, örgütsel bağl1lık ve örgütsel özdeşleşme arasındaki ilişkileri belirlemeye ilişkin yapılan bu çalışmadan elde edilen veriler sosyal bilimlerde kullanılan bir istatistik programı ile değerlendirilmiştir. Kocaeli ilindeki kamu hastane çalışanlarına ait demografik bilgiler yüzde ve frekans yöntemiyle çözümlenmiştir. Kullanılan dört ölçeğin geçerlilik ve güvenilirliği Cronbach's Alpha değeri ile ortaya konmuştur. Faktör analizi ile yapı geçerliliği hesaplanmıştır. Sağlık çalışanlarının algıladıkları örgütsel destek, örgütsel güven ve örgütsel bağlılık ile örgütsel özdeşleşme davranışları arasındaki ilişki Pearson korelasyon katsayısı ile belirlenmiştir. Doğrusal regresyon modeli ile sağlık çalışanlarının örgütsel destek, örgütsel güven, örgütsel bağlılık ve örgütsel özdeşleşme arasındaki birbirlerine etkileri tespit edilmiştir.

\section{BULGULAR}

Araştırmaya katılan Kocaeli ili kamu hastane çalışanlarının bireysel ve hastanelere ilişkin bulguları incelendiğinde, çalışanların büyük ölçüde $(\% 68,9)$ bayan olduğu, 30 yaşın altında $(\% 58)$ ve bekar $(\% 55,3)$ çalışanlardan oluştuğu görülmüştür. Katılımclların çoğunun $(\% 47,5)$ lisans, $(\% 46,6)$ lise mezunu olarak çalıştıkları görülmektedir. Bu duruma göre araştırmaya katılanların yaklaşık yarısının lisans mezunu olması eğitim oranının arttığını göstermektedir. Çalışanların kıdemleri incelendiğinde 1-5 yıl $(\% 61,6)$ arası çalışanların ağırlıklı olduğu belirlenmiştir. Yaşla ilgili bilgilerle doğru orantılı olarak kıdemin de fazla olmadığı görülmektedir. Gelir düzeyleri incelendiğinde ise çalışanların çoğunluğu 4001-5000 TL arası gelire sahip $(\% 39,6)$ bireylerden oluştuğu saptanmıştır. Katılımcıların kamu hastanelerinde çalıştıkları bölüme ilişkin bulgulara bakıldığında hasta yoğunluğuna bağlı olarak $(\% 27,1)$ ile servislerde, $(\% 25,1)$ ile poliklinik hizmetinde, $(\% 15,9)$ ile az çalışanın olduğu "diğer" olarak adlandırılan hizmetlerde, $(\% 11,6)$ ile radyoloji bölümünde, $(\% 7,7)$ ile ameliyathane hizmetlerinde, $(\% 6,3)$ ile doğum odasında, $(\% 5,8)$ ile laboratuvar bölümünde, $(0,5)$ ile yoğun bakımda görev aldıkları belirlenmiştir. Katılımcılar $(\% 35,3)$ ile hemşire, $(\% 19,8)$ ile sağlık personeli, $(\% 13,5)$ ile sağlık memuru, $(\% 11,1)$ ile radyoloji teknikeri, $(\% 7,7)$ ile ebe, $(\% 6,3)$ ile doktor, $(\% 5,8)$ ile laboratuvar teknikeri olarak çalışmaktadır. Covid19 Pandemi döneminde işe gelmeme ve geç kalma açısından değerlendirilen çalışanların $(\% 74,9)$ gibi bir oranda hiç gelmemezlik yapmadıkları $(\% 81,6)$ oranında hiç işe geç kalmadıkları tespit edilmiştir.

Varimaks dönüşümlü keşifsel faktör analizi kullanılarak değişkenlere ilişkin faktör yapısı ortaya çıkarılmıştır. Sağlık çalışanlarına 6 soru sorularak örgütsel özdeşleşme ölçülmüştür. Tablo 1'de örgütsel özdeşleşme için uygulanan faktör analizinin sonuçları görülmektedir. Yapılan faktör analizi ile tek boyutlu ölçeğin faktör yükleri tespit edilmiştir. Faktörler yüksek düzeyde güvenilirlik katsayılarına sahiptir. Faktör yük değerlerinin 0,50 üzerinde olması hedeflenmiş ve sonuçlar bu doğrultuda çıkmıştır. KMO (yeterlilik katsayısı), 826 olarak tespit edilmiştir. Tüm bu sonuçlar örgütsel özdeşleşmenin bir bütün olarak içsel tutarlılı̆̆a sahip olduğunu göstermektedir.

Tablo 1.Örgütsel Özdeşleşme ile İlgili Faktör Analizleri

\begin{tabular}{|c|c|}
\hline İfadeler & Faktör1 \\
\hline Kurumumu herhangi bir kişi eleştirdiğinde, kendimi kötü hissederim. & 761 \\
\hline Çalıştığım kurum hakkında diğer insanların düşünceleri önemlidir. & 691 \\
\hline Kurumum konusunda, genellikle "onlar" yerine "biz" kelimesini kullanırm. & 653 \\
\hline Kurumumun başarısı bana kendi başarım gibi gelir. & ,785 \\
\hline Kurumumu biri övdü̈̆̈̈̈nde, kendime yapılan bir övgü gibi düşünürüm. & ,804 \\
\hline Kurumumla ilgili medyada bir eleştiri yapıldığında, rahatsı olurum. & 763 \\
\hline
\end{tabular}


Büyüköztürk (2003:124) faktör yükleri ile ilgili olarak, az sayıda ifade için 0,30'a düşürülebileceğini, 0,45 ve üzerinde olmasının gerektiğini ifade etmektedir. Faktörler arası ilişki yapısının değişmemesi için varimax yöntemi kullanılmıştır. Faktör yükleri 0,653 ve 0,804 arasında değişiklik göstermektedir. Yapılan faktör analizi ile ölçeğin öz değerinin 1'den büyük olduğu görülmektedir. Toplam açılanan varyansın \%55,473 olan tek faktör altında toplandığı tespit edilmiştir. Örgütsel Özdeşleşme Ölçeği'nin geçerli bir ölçme aracı olduğu açıklanan varyans değeri ile anlaşılmıştır. Özdeşleşme Ölçeği için Cronbach's Alpha değeri incelendiğinde $(\alpha=0,838)$ olarak hesaplandığı ve ölçeğin güvenilir olduğu belirlenmiştir. Ural ve Kılıç (2018: 268) güvenirlik katsayısı için 0 ile 1 arasında değerler alındığını ve sonuç değerin 1'e yakın olmasının güvenirlik düzeyinin yüksek olduğu anlamına geldiğini belirtmiştir.

Tablo 2.Örgütsel Destek ile İlgili Faktör Analizleri

\begin{tabular}{lc}
\hline \multicolumn{1}{c}{ İfadeler } & Faktör1 \\
\hline Kurumum görüşlerimi dikkate alır. & $\mathbf{0 , 8 0 6}$ \\
Kurumum gerçekten benim refahımı düşünür. & $\mathbf{0 , 9 0 1}$ \\
Amaçlarım, değerlerim kurumum tarafından çok önemsenir. & $\mathbf{0 , 8 8 0}$ \\
Bir sorunla karşılaştı̆̆ımda, kurumum bana yardımcı olur. & $\mathbf{0 , 8 3 0}$ \\
Kurumum, kabul edilebilir hatalarımı bağışlar. & $\mathbf{0 , 5 8 3}$ \\
Özel bir yardıma ihtiyaç duyduğumda, kurumum yardım etmede istekli davranır. & $\mathbf{0 , 6 7 1}$ \\
\hline
\end{tabular}

1.Faktör: Örgütsel Destek; $\alpha$ : Cronbach's Alpha Değeri:0,871; Kaiser-Meyer-Olkin değeri (KMO)=0,830; Bartlett's Testi: X2=650,128; $p=0,000$

Tablo 2' de Örgütsel Destek için uygulanan faktör analizinin sonuçları görülmektedir. Faktör yüklerinin düşük olması sebebiyle iki ifade kapsam dışı bırakılmıştır. Faktör analizi sonucuna göre faktör yüklerinin 0,583 ile 0,901 arasında değişiklik gösterdiği görülmektedir. Bununla birlikte, faktör analizinde ölçeğin öz değerinin 1'den büyük ve toplam açıklanan varyansın \%61,885'ini açıklayan tek faktör altında toplandığ 1 belirlenmiştir. Açılanan varyans değerine göre Örgütsel Destek Ölçeği'nin geçerli ölçme aracı olduğu anlaşılmıştır. Örgütsel Destek Ölçeğine ilişkin Cronbach's Alpha değeri incelendiğinde genel güvenirlik düzeyi $(\alpha=0,871)$ olarak hesaplanmıştır.

Tablo 3.Örgütsel Güven ile İlgili Faktör Analizleri

\begin{tabular}{|c|c|c|}
\hline İfadeler & Faktör1 & Faktör2 \\
\hline Yöneticimin işte önemli konularda teknik yeterliliğine güvenim tamdır. & 0,778 & \\
\hline $\begin{array}{l}\text { Yöneticimin işiyle ilgili kararları üzerinde iyi düşünerek alacă̆ına olan güvenim } \\
\text { tamdır. }\end{array}$ & 0,821 & \\
\hline Yöneticimin işi bırakmayacă̆ına güvenim tamdır. & 0,772 & \\
\hline $\begin{array}{l}\text { Yöneticimin işiyle ilgili kavrama yeteneğinin makul düzeyde olduğuna ilişkin } \\
\text { güvenim tamdır. }\end{array}$ & 0,590 & \\
\hline Yöneticimin işini makul düzeyde yaptı̆̆ına olan güvenim tamdır. & 0,896 & \\
\hline Yöneticimin her konuda söylediklerinin doğruluğuna ilişkin güvenim tamdır. & 0,857 & \\
\hline $\begin{array}{l}\text { Yöneticimin farklı sorunlara yol açmadan işini tamamlayabileceğine güvenim } \\
\text { tamdır. }\end{array}$ & 0,846 & \\
\hline $\begin{array}{l}\text { Yöneticimin İşi esnasında dikkatli bir şekilde yaptıkların düşüneceğine olan } \\
\text { güvenim tamdır. }\end{array}$ & 0,836 & \\
\hline Kurumumun bana adil davranacă̆ına ilişkin güvenim tamdır & & 0,648 \\
\hline Kurumumdaki yöneticiler ve çalışanlarm birbirine güven düzeyi çok yüksektir & & 0,703 \\
\hline Çalıştığım ortamda kişiler arasındaki güven düzeyi çok yüksektir & & 0,793 \\
\hline Kurumumda birbirimize güvenme düzeyi cok yüksektir & & 0,656 \\
\hline
\end{tabular}

1.Faktör: Yöneticiye Güven( $\alpha:$;,899),2.Faktör:Örgüte Güven( $\alpha:$;647); Kaiser-Meyer-Olkin değeri (KMO)=0,921;Bartlett's Testi: X2=2251,46;p=0,000

Tablo 3'de Örgütsel Güven için uygulanan faktör analizinin sonuçları görülmektedir. Yapılan faktör analizine göre faktör yüklerinin 0,590 ile 0,896 arasında değişiklik gösterdiği görülmektedir. Bununla birlikte, faktör analizinde ölçeğin öz değerinin 1'den büyük ve toplam açıklanan varyansın \%70,264'ünü açıklayan iki faktör altında toplandığı belirlenmiştir. Birinci boyut "yöneticiye güven" boyutu toplam varyansın \%47,270'ini, ikinci boyut "örgüte güven" boyutu toplam varyansın \%22,993'ünü açıkladığı görülmektedir. Açıklanan varyans değerine göre Örgütsel Güven Ölçeği'nin geçerli ölçme aracı olduğu anlaşılmıştır. Örgütsel Güven 
Ölçeğine ilişkin Cronbach's Alpha değeri incelendiğinde genel güvenirlik düzeyi $(\alpha=0,880)$ olarak hesaplanmıştır.

Tablo 4.Örgütsel Bağlllık ile İlgili Faktör Analizleri

\begin{tabular}{lc}
\hline \multicolumn{1}{c}{ İfadeler } & Faktör1 \\
\hline Kurumum benim için kişisel bir anlam ifade etmektedir. & $\mathbf{0 , 7 9 9}$ \\
Kurumuma karşı güçlü bir bağhlık hissediyorum. & $\mathbf{0 , 8 9 9}$ \\
Kurumumda kendimi ailenin bir parçası gibi hissediyorum. & $\mathbf{0 , 8 9 6}$ \\
Kurumuma kendimi duygusal olarak bağhl hissediyorum. & $\mathbf{0 , 8 9 3}$ \\
\hline
\end{tabular}

1.Faktör: Örgütsel Bă̆lllık; $\alpha$ : Cronbach's Alpha Değeri:0,896; Kaiser-Meyer-Olkin değeri (KMO)=0,816; Bartlett's Testi: X2=512,999; $p=0,000$

Tablo 4'te Örgütsel Bağlılık için uygulanan faktör analizinin sonuçları görülmektedir. Faktör analizi sonucuna göre faktör yüklerinin 0,799 ile 0,899 arasında değişiklik gösterdiği görülmektedir. Bununla birlikte, faktör analizinde ölçeğin öz değerinin 1'den büyük ve toplam açıklanan varyansın \%76,204'ünü açıklayan tek faktör altında toplandığı belirlenmiştir. Açıklanan varyans değerine göre Örgütsel Bağlılık Ölçeği'nin geçerli ölçme aracı olduğu anlaşılmıştır. Örgütsel Bağlllık Ölçeğine ilişkin Cronbach's Alpha değeri incelendiğinde genel güvenirlik düzeyi $(\alpha=0,896)$ olarak hesaplanmıştır.

Örgütsel destek, örgüte güven, örgütsel bağlllık ve örgütsel özdeşleşme arasındaki ilişkilere ilişkin uygulanan "korelasyon analizi" Tablo 5'te verilmektedir. Bulgulara bakıldığında, örgütsel destek, örgütsel güven(yöneticiye güven, örgüte güven), örgütsel bağlılık ve örgütsel özdeşleşme arasında 0,01 anlamlılık seviyesinde önemli ilişkiler tespit edilmiştir. Yani bütün faktörler Pearson Korelasyon Katsayısı(r) istatistiksel olarak anlamlıdır $(\mathrm{p}<0,01)$.

Tablo 5. Örgütsel Özdeşleşme, Destek, Güven ve Bağl1lık Davranışları Arasındaki İlişkilere Yönelik Korelasyon Analizi

\begin{tabular}{|c|c|c|c|c|c|}
\hline & 1 & 2 & 3 & 4 & 5 \\
\hline 1.Örgütsel Özdeşleşme & $(0,838)$ & & & & \\
\hline 2.Örgütsel Destek & $0,369^{* *}$ & $(0,871)$ & & & \\
\hline 3.Yöneticiye Güven & $0,343^{* *}$ & $0,554^{* *}$ & $(0,899)$ & & \\
\hline 4.Örgüte Güven & $0,301^{* *}$ & $0,394^{* *}$ & $0,550^{* *}$ & $(0,647)$ & \\
\hline 5.Örgütsel Bağlılık & $0,616^{* *}$ & $0,428^{* *}$ & $0,319^{* *}$ & $0,328^{* *}$ & $(0,896)$ \\
\hline
\end{tabular}

${ }^{* *} p<0,01 ; * p<0,05$ r:Pearson Korelasyon Katsayısl

Örgütsel özdeşleşme ile örgütsel destek $(r=0,369)$, yöneticiye güven $(r=0,343)$, örgüte güven $(r=0,301)$ arasında çok güçlü olmayan anlamlı ilişkiler tespit edilmiştir. Örgütsel özdeşleşme ve örgütsel bağlllık $(r=0,616)$ arasında güçlü sayılabilecek bir anlamlı ilişki saptanmıştır. İlgili literatürde bahsi geçen değişkenler ve örgütsel özdeşleşme arasında benzer sonuçların görüldüğü pozitif yönlü ve anlamlı ilişki bulunan (Öktem vd.,2016; Taşkın, Dilek,2010; Çakınberk vd., 2011) çalışmalar bulunmaktadır.

Örgütsel destek ile yöneticiye güven $(r=0,554)$, örgüte güven(r=0,394), ve örgütsel bağlllık $(r=0,428)$ arasında orta düzeyde kabul edilebilecek anlamlı ilişkiler bulgulanmıştır. İlgili literatürde bahsi geçen değişkenler ve örgütsel destek arasında benzer sonuçların görüldüğü pozitif yönlü ve anlamlı ilişki bulunan (Özdevecioğlu, 2003; Naktiyok, İşcan,2019; Turunç, Çelik,2010) çalışmalar bulunmaktadır.

Yöneticiye güven ile örgüte güven $(r=0,550)$ arasında orta düzeyde anlamlı bir ilişki tespit edilmiştir. Yöneticiye güven ve Örgütsel bağlllık $(\mathrm{r}=0,319)$ arasında zayıf sayılabilecek anlamlı ilişki görülmektedir. Örgüte güven ile Örgütsel bağlılık $(\mathrm{r}=0,328)$ arasında yine zayıf kabul edilebilecek anlamlı ilişki söz konusudur. İlgili literatürde bahsi geçen değişkenler arasında benzer sonuçların görüldüğü pozitif yönlü ve anlamlı ilişki bulunan (Taşkın ve Dilek, 2010; Demirel, 2008) çalışmalar bulunmaktadır.

Araştırma bulgularını değerlendirme sürecinde örgütsel özdeşleşme, örgütsel destek, örgütsel güven boyutları, örgütsel bağlılık davranışları arasındaki ilişkinin değerlendirilmesinden sonra araştırma hipotezlerinin test edilmesi amaciyla basit doğrusal regresyon analizi gerçekleştirilmiş ve bulgular Tablo 6 , Tablo 7 ve Tablo 8 'da sunulmuştur. 
Tablo 6. Örgütsel Desteğin Örgütsel Özdeşleşme Üzerindeki Etkilerine Yönelik Regresyon Analizi Sonuçları

\begin{tabular}{|c|c|c|}
\hline & \multicolumn{2}{|c|}{$\begin{array}{l}\text { Bağımlı Değişken } \\
\text { Örgütsel Özdeşleşme }\end{array}$} \\
\hline Bağımsız Değişken & B & $\mathrm{T}$ \\
\hline Örgütsel Destek & 0,369 & $5,680^{* *}$ \\
\hline Model F & \multicolumn{2}{|c|}{$32,268^{* *}$} \\
\hline Model R2 & \multicolumn{2}{|c|}{0,136} \\
\hline & \multicolumn{2}{|c|}{${ }^{*} 0,05$ düzeyinde anlaml ${ }^{* *} 0,01$ düzeyinde anlamlı } \\
\hline
\end{tabular}

Örgütsel özdeşleşme ile örgütsel destek arasındaki ilişkinin belirlenmesi amacıyla yapılan regresyon analizi istatistiksel olarak anlamlı bulunmuştur $(\mathrm{F}=32,268 ; \mathrm{P}=0,000)$. Sağlık çalışanlarının algıladıkları örgütsel desteğin örgütsel özdeşleşme davranışını pozitif ve anlamlı olarak etkilediği tespit edilmiştir. Böylece "H1:Sağlık çalışanları örgütsel destek algısı örgütsel özdeşleşmeyi pozitif yönde etkiler" şeklindeki hipotez desteklenmektedir.

Tablo 7. Örgütsel Güvenin Örgütsel Özdeşleşme Üzerindeki Etkilerine Yönelik Regresyon Analizi Sonuçları

\begin{tabular}{lcc}
\hline & \multicolumn{3}{c}{ Bağımlı Değişken } \\
Örgütsel Özdeşleşme \\
\hline Bağımsız Değişken & $\mathrm{T}$ \\
Yöneticiye Güven & 0,254 & $3,261^{* *}$ \\
Örgüte Güven & 0,161 & $2,068^{*}$ \\
Model F & & $\mathbf{1 5 , 9 9 7 ^ { * * }}$ \\
Model R2 & 0,136 \\
& ${ }^{*} 0,05$ düzeyinde anlaml ${ }^{* *} 0,01$ düzeyinde anlamlı \\
\hline
\end{tabular}

Örgütsel özdeşleşme ile örgütsel güven arasındaki ilişkinin belirlenmesi amacıyla yapılan regresyon analizi istatistiksel olarak anlamlı bulunmuştur $(\mathrm{F}=15,997 ; \mathrm{P}=0,000)$. Daha önce ifade edildiği üzere güven değişkeni iki boyutludur. Hem yöneticiye güven boyutu hem de örgüte güven boyutu örgütsel özdeşleşmeyi pozitif ve anlamlı olarak etkilemektedir. Böylece "H2:Sağllk çalışanlarının yöneticiye güven algılarının örgütsel özdeşleşme üzerinde pozitif yönlü ve anlamlı bir etkisi vardır" ve "H3:Sağlık çalışanlarının örgüte güven algılarının örgütsel özdeşleşme üzerinde pozitif yönlü ve anlamlı bir etkisi vardır" şeklindeki hipotezi desteklenmektedir.

Tablo 8. Örgütsel Bağlllı̆̆ın Örgütsel Özdeşleşme Üzerindeki Etkilerine Yönelik Regresyon Analizi Sonuçları

\begin{tabular}{|c|c|c|}
\hline & \multicolumn{2}{|c|}{$\begin{array}{l}\text { Bağımlı Değişken } \\
\text { Örgütsel Özdeşleşme }\end{array}$} \\
\hline Bağımsız Değişken & B & $\mathrm{T}$ \\
\hline Örgütsel Bağlllık & 0,616 & $11,203^{* *}$ \\
\hline Model F & \multicolumn{2}{|c|}{$125,511 * *$} \\
\hline Model R2 & \multicolumn{2}{|c|}{0,136} \\
\hline & \multicolumn{2}{|c|}{${ }^{*} 0,05$ düzeyinde anlaml ${ }^{* *} 0,01$ düzeyinde anlamlı } \\
\hline
\end{tabular}

Örgütsel özdeşleşme ile örgütsel bağlllık arasındaki ilişkinin belirlenmesi amacıyla yapılan regresyon analizi istatistiksel olarak anlamlı bulunmuştur ( $\mathrm{F}=125,511 ; \mathrm{P}=0,000)$. Sağlık çalışanlarının duydukları örgütsel bağlılığın örgütsel özdeşleşme davranışını pozitif ve anlamlı olarak etkilediği tespit edilmiştir. Böylece "H4:Sağlık çalışanlarının örgütsel bağlllık davranışlarının örgütsel özdeşleşme üzerinde pozitif yönlü ve anlamlı bir etkisi vardır" şeklindeki hipotezi desteklenmektedir.

Araştırma bulgularını değerlendirme sürecinde örgütsel destek, örgütsel güven boyutları ve örgütsel bağlllı̆̆ın örgütsel özdeşleşme üzerindeki etkilerinin test edilmesinin yanı sıra örgütsel desteğin örgütsel bağlllık ve güven boyutları üzerindeki etkileri de test edilmiştir. Ayrıca yöneticiye güven ve örgüte güvenin örgütsel bağlllık üzerindeki etkileri de regresyon analizi ile değerlendirilmiştir. Tablo 9, Tablo 10 ve Tablo 11ve Tab12'de sunulmuştur. 
Tablo 9. Örgütsel Desteğin Örgütsel Bağllılı Üzerindeki Etkilerine Yönelik Regresyon Analizi Sonuçları

\begin{tabular}{|c|c|c|}
\hline & \multicolumn{2}{|c|}{$\begin{array}{l}\text { Bağımlı Değişken } \\
\text { Örgütsel Bağlılık }\end{array}$} \\
\hline Bağımsız Değişken & $\bar{B}$ & $\mathrm{~T}$ \\
\hline Örgütsel Destek & 0,428 & $6,781^{* *}$ \\
\hline Model F & \multicolumn{2}{|c|}{$45,981^{* *}$} \\
\hline Model R2 & \multicolumn{2}{|c|}{0,183} \\
\hline & \multicolumn{2}{|c|}{${ }^{*} 0,05$ düzeyinde anlaml ${ }^{* *} 0,01$ düzeyinde anlamlı } \\
\hline
\end{tabular}

Örgütsel bağl1lık ile örgütsel destek arasındaki ilişkiyi belirlenmesi amacıyla yapılan regresyon analizi istatistiksel olarak anlamlı bulunmuştur $(\mathrm{F}=45,981 ; \mathrm{P}=0,000)$. Sağlık çalışanlarının duydukları örgütsel desteğin örgütsel bağlılık davranışını pozitif ve anlamlı olarak etkilediği tespit edilmiştir. Böylece "H5: Sağlık çalışanlarının örgütsel destek algılarının örgütsel bağlılık üzerinde pozitif yönlü ve anlamlı bir etkisi vardır" şeklindeki hipotezi desteklenmektedir.

Tablo 10. Örgütsel Desteğin Yöneticiye Güven Üzerindeki Etkilerine Yönelik Regresyon Analizi Sonuçları

\begin{tabular}{lcc}
\hline & \multicolumn{3}{c}{$\begin{array}{c}\text { Bağımlı Değişken } \\
\text { Yöneticiye Güven }\end{array}$} \\
\hline Bağımsız Değişken & & $\mathrm{T}$ \\
Örgütsel Destek & $\mathrm{B}$ & $9,516^{* *}$ \\
Model F & 0,554 & $\mathbf{9 0 , 5 6 3 ^ { * * }}$ \\
Model R2 & 0,306 & \\
& & ${ }^{*} 0,05$ düzeyinde anlamlı ${ }^{* *} 0,01$ düzeyinde anlamlı \\
\hline
\end{tabular}

Yöneticiye güven ile örgütsel destek arasındaki ilişkiyi belirlenmesi amacıyla yapılan regresyon analizi istatistiksel olarak anlamlı bulunmuştur $(\mathrm{F}=90,563 ; \mathrm{P}=0,000)$. Sağlık çalışanlarının algıladıkları örgütsel desteğin yöneticiye güven davranışını pozitif ve anlamlı olarak etkilediği tespit edilmiştir. Böylece "H6: Sağlık çalışanlarının örgütsel destek algılarının yöneticiye güven üzerinde pozitif yönlü ve anlamlı bir etkisi vardır" şeklindeki hipotezi desteklenmektedir.

Tablo 11. Örgütsel Desteğin Örgüte Güven Üzerindeki Etkilerine Yönelik Regresyon Analizi Sonuçları

\begin{tabular}{|c|c|c|}
\hline & \multicolumn{2}{|c|}{$\begin{array}{c}\text { Bağımlı Değişken } \\
\text { Örgüte Güven }\end{array}$} \\
\hline Bağımsız Değişken & B & $\mathrm{T}$ \\
\hline Örgütsel Destek & 0,394 & $6,131^{* *}$ \\
\hline Model F & \multicolumn{2}{|c|}{$37,585^{* *}$} \\
\hline Model R2 & \multicolumn{2}{|c|}{0,155} \\
\hline & \multicolumn{2}{|c|}{${ }^{*} 0,05$ düzeyinde anlaml ${ }^{* *} 0,01$ düzeyinde anlamlı } \\
\hline
\end{tabular}

Örgüte güven ile örgütsel destek arasındaki ilişkinin belirlenmesi amacıyla yapılan regresyon analizi istatistiksel olarak anlamlı bulunmuştur $(\mathrm{F}=37,585 ; \mathrm{P}=0,000)$. Sağlık çalışanlarının algıladıkları örgütsel desteğin örgüte güven davranışını pozitif ve anlamlı olarak etkilediği tespit edilmiştir. Böylece "H7: Sağlık çalışanlarının örgütsel destek algılarının örgüte güven üzerinde pozitif yönlü ve anlamlı bir etkisi vardır" şeklindeki hipotezi desteklenmektedir.

Tablo 12. Yöneticiye ve Örgüte Güvenin Örgütsel Bağlllık Üzerindeki Etkilerine Yönelik Regresyon Analizi Sonuçları

\begin{tabular}{|c|c|c|}
\hline & \multicolumn{2}{|c|}{$\begin{array}{l}\text { Bağımlı Değişken } \\
\text { Örgütsel Bağlılık }\end{array}$} \\
\hline Bağımsız Değişken & B & $\mathrm{T}$ \\
\hline Yöneticiye Güven & 0,199 & $2,554^{* *}$ \\
\hline Örgüte Güven & 0,219 & $2,805^{* *}$ \\
\hline Model F & \multicolumn{2}{|c|}{$15,953^{* *}$} \\
\hline Model R2 & \multicolumn{2}{|c|}{0,135} \\
\hline & \multicolumn{2}{|c|}{${ }^{*} 0,05$ düzeyinde anlaml ${ }_{1}^{* *} 0,01$ düzeyinde anlamlı } \\
\hline
\end{tabular}


Örgütsel bağlılık ile yöneticiye güven ve örgüte güven arasındaki ilişkinin belirlenmesi amacıyla yapılan regresyon analizi istatistiksel olarak anlamlı bulunmuştur ( $F=15,953 ; P=0,000)$. Sağlık çalışanlarının duydukları yöneticiye güven ve örgüte güven hissinin örgütsel bağlılık davranışını pozitif ve anlamlı olarak etkilediği tespit edilmiştir. Böylece "H8: Sağlık çalışanlarının yöneticiye güven duygusunun örgütsel bağlllık üzerinde pozitif yönlü ve anlamlı bir etkisi vardır" şeklindeki hipotezi desteklenmektedir. Ayrıca "H9: Sağlık çalışanlarının örgüte güven duygusunun örgütsel bağlılık üzerinde pozitif yönlü ve anlamlı bir etkisi vardır" hipotezi de desteklenmektedir.

\section{SONUÇ VE TARTIŞMA}

Örgütsel özdeşleşme, örgütsel bağl1lık, örgütsel güven ve örgütsel destek ilişkilerinin araştırıldı̆̆ bu çalışmada teorik ve pratik açıdan önemli bulgular elde edilmiştir. Araştırmada dokuz adet hipotez kurularak, bahsi geçen değişkenler arasındaki ilişkiler tespit edilmiştir.

Örgüt, işgörenlerin örgüte katkılarının farkında olarak, mutluluklarına önem vererek, birlikte çalışmaktan memnuniyetini belirterek, ait olma, saygı ve onaylama ihtiyacını karşılayarak örgütsel destek sunmaktadır (Armeli vd.,1998:299). Bu doğrultuda örgütsel desteğin; örgütsel bağlllık, örgüte güven, yöneticiye güven ve örgütsel özdeşleşmeyi olumlu yönde etkileyeceği yönündeki hipotezleri kabul edilmiştir. Araştırma bulguları ilgili yazınla örtüşmektedir (Rhoades ve Eisenberger ,2002; Chen vd., 2003; DeConinck, 2010; Cheung, Law, 2008; Turunç, Çelik,2010). Çalışanlar iş ortamında destek beklentisi içindedir. Bu beklentinin farkına varan yöneticiler, gerekli desteği verdikleri taktirde çok önemli rekabet avantajı elde etmektedir.

Güvenin olmadığı bir iş ortamında çalışanların örgülerine bağlılığının da düşük olması beklenen bir durumdur. Hatta düşük örgütsel bağlllığa sahip çalışanların olduğu bir örgütte performans, başarı da düşük olacaktır. Bu doğrultuda örgütsel güvenin örgüte güven ve yöneticiye güven boyutlarının; örgütsel özdeşleşme ve örgütsel bağlılı̆̆1 olumlu yönde etkileyeceği hipotezleri kabul edilmiştir. Araştırma bulguları literatürü destekler niteliktedir (Tokgöz, Seymen, 2013; Taşkın,Dilek, 2010; Demirel, 2008). Günümüzde örgütlerin rekabet gücü için, varlığını bugün ve gelecekte koruyabilmesi için örgütsel güvenin geliştirilmesi çok önemlidir. Eğer çalışanlar kendilerine güvenirse, yöneticilerine ve örgütüne güvenirse daha yüksek performans göstermeleri, geleceğe karşı güvenli olmaları, krizlerde hayatlarını sürdürebilmeleri kuvvetle muhtemeldir. Güvenin olmadığı bir iş ortamında çalışanların örgülerine bağlılığının düşük olması beklenen bir durumdur. Hatta düşük örgütsel bağlılığa sahip çalışanların olduğu bir örgütte performans, başarı da düşük olacaktır.

Örgütsel bağl1lık ve özdeşleşme, araştırmacıların çalışan-örgüt ilişkisini incelemek için kullandıkları iki yapıdır. Bu doğrultuda örgütsel özdeşleşmenin; örgütsel bağlıllı̆̆ olumlu yönde etkileyeceği hipotezi kabul edilmiştir. Araştırma bulguları literatürü destekler niteliktedir (Sass, Canary,1991; Tyler, Blader,2001; Çakınberk vd.,2011; Sökmen,2019). Örgüt yöneticilerinin işgören davranış, tutum ve duygularını keşfetmesi önemlidir. İşgörenlerin davranışlarının sebepleri tespit edildiğinde koşullar yenilenebilir. Hem örgüt için hem de işgörenler için elverişli, olumlu bir iş ortamı sağlanabilirse, başarı kaçınılmaz olacaktır.

Bu çalışmada, sağlık çalışanlarının örgütsel özdeşleşme, örgütsel bağlllık, örgütsel güven ve örgütsel destek algısı olmak üzere dört olumlu iş tutumu araştırılmıştır. Bulgular doğrultusunda sağlık çalışanlarının örgütsel destek düzeyi yüksek, örgütsel güven hisseden, örgütsel bağlllı̆̆ı yüksek ve örgütü ile özdeşleşmiş bireyler oldukları ifade edilebilir. Literatürde tüm değişkenlerin birlikte ele alındığı çalışma yok denecek kadar azdır. Örgütler için yetişmiş insan gücü son derece önemlidir. Artan işgücü devir oranı son derece olumsuz bir durumdur. Bu doğrultuda örgütlerin yetişmiş insan gücünü örgütte kalıcı kılabilmek için olumlu iş tutumları üzerinde odaklanmaları gerekmektedir. Sağlık çalışanlarının şartları iyileştirilmeli, değer verilmeli, olumlu bir örgüt iklimi sağlanmalıdır. Örgütlerin başarıyı yakalamasında en önemli faktör olan insan kaynağının desteklenmesi, örgüte ve yöneticiye güven ortamının yaratılması çok önemlidir. Gelecekteki çalışmalar için farklı kültürlerde, farklı sektörlerde aynı değişkenlerin incelenmesi ve sağlık çalışanlarında kamu, özel karşılaştırılması önerilmektedir. 


\section{KAYNAKÇA}

Akkaya, B. (2020). Linking Organizational Commitment and Organizational Trust in Health Care Organizations, Organizacija ,53(4), 306-318.

Armeli, S., Eisenberger, R., Fasolo, P., \& Lynch, P. (1998). Perceived organizational support and police performance: The moderating influence of socioemotional needs. Journal of Applied Psychology, 83, 288297.

Aselage, J.,\& Eisenberger, R. (2003). Perceived organizational support and psychological contracts: A theoretical integration. Journal of Organizational Behavior, 24, 491-509.

Ashforth, B.E. ve Mael, F. (1989), "Social identity theory and the organization", Academy of Management Review, 14(1), 20-39.

Asunakutlu, T. (2006)."Çalışanlar ile yöneticiler arasında güven duygusunun araştırılması: Turizm sektöründe bir uygulama", Dokuz Eylül Üniversitesi Sosyal Bilimler Enstitüsü Dergisi, 8(4), 16-33.

Aube, C.; Rousseau, V. ve Morin, E. M. (2007). Perceived organizational support and organizational commitment. Journal of Managerial Psychology, 22, 479-495

Baltacı, A. (2018). Nitel Araştırmalarda Örnekleme Yöntemleri ve Örnek Hacmi Sorunsalı Üzerine Kavramsal Bir İnceleme. BEÜ SBE Dergisi,7(1), 231-274.

Bedeian, A.G. (2007), "Even if the Tower Is "Ivory," It Isn't “White:" Understanding the Consequences of Faculty Cynicism", Academy of Management Learning \& Education, 6(1), 9-32.

Biçkes, D. M. ve Yılmaz, C. (2017). Çalışanların Örgütsel Güven Algılamalarının Özdeşleşme Düzeyleri Üzerindeki Etkisi: Ampirik Bir Çalı̧̧ma. KSÜ Sosyal Bilimler Dergisi. 14(1), 301-322

Büte, M. (2011). Etik iklim, örgütsel güven ve bireysel performans arasındaki ilişki. Atatürk Üniversitesi İktisadi ve İdari Bilimler Dergisi, 25(1), 171-192.

Büyüköztürk, Ş. (2003). Sosyal Bilimler İçin Veri Analizi El Kitabı, Ankara: Pegem Akademi Yayıncılık.

Campbell, Jesse W. and Im, Tobin (2015). “Identification and trust in public organizations: A communicative approach", Public Management Review, 17(8), 1065-1084.

Candan, H. ve İnce, M. (2016). Siber Kaytarma ve Örgütsel Bağlılık Arasındaki İlişkinin İncelenmesine Yönelik Emniyet Çalışanları Üzerine Bir Araştırma, Niğde Üniversitesi İIBF Dergisi, 9(1), 229-235.

Chen, Zehn Xiong ve Francesco, Anne Marie (2003), “The Relationship Between The Three Components Of Commitment and Employee Performance in China", Journal of Vocational Behavior, 62(3), 490-516.

Chen, Z., Aryee, S., \& Lee, C. 2005. Test of a mediation model of perceived organizational support. Journal of Vocational Behavior, 66,457-470.

Chen, S. Y., Wu, W. C., Chang, C. S., Lin, C. T., Kung, J. Y., Weng, H. C.,Lin, Y. T., \& Lee, S. I. (2015). Organizational Justice, Trust, and Identification and Their Effects on Organizational Commitment in Hospital Nursing Staff. BMC Health Services Research, 15(363), 1-17.

Cheung, M. F. Y. ve Law M. C. C. (2008). "Relationships of Organizational Justice and Organizational Identification:The Mediating Effects of Perceived Organizational Support in Hong Kong", Asia Pacific Business Revie, 14 (2), 213-231.

Cho, Y.J. ve Park, H.J. (2011).“Exploring the Relationships Among Trust, Employee Satisfaction, and Organizational Commitment", Public Management Review, 13(4), 551-573.

Chughtai, Aamir Ali ve Sohail Zafar (2006). "Antecedents and Consequences of Organizational Commitment among Pakistani University Teachers", Applied H.R.M. Research, 11(1), 39-64

Çakar, D. Ve Yıldız, S. (2009). “Örgütsel Adaletin İş Tatmini Üzerindeki Etkisi: “Algılanan Örgütsel Destek” Bir Ara Değişken mi?", Elektronik Sosyal Bilimler Dergisi, 8(28), 68-90 
Çakınberk, A., Derin, N. Ve Demirel, E. (2011). Örgütsel özdeşleşmenin örgütsel bağlllıkla biçimlenmesi: Malatya ve Tunceli özel eğitim kurumları örneği. İşletme Araştırmaları Dergisi, 3(1), 89-121.

Çankaya, M., Örgütsel Güvenin Örgütsel Özdeşleşme Üzerindeki Etkisi: Sağlık Sektöründe Bir Uygulama. Akademik Sosyal Araştırmalar Dergisi, 107,185-204.

Çubukçu, K. ve Tarakçığlu, S. (2010). Örgütsel güven ve bağlılık ilişkisinin otelcilik ve turizm meslek lisesi öğretmenleri üzerinde incelenmesi. İşletme Araştırmaları Dergisi, 2 (4), 57-58.

DeConinck, J. B. (2010). The effect of organizational justice, perceived organizational support, and perceived supervisor support on marketing employees' level of trust. Journal of Business Research, 63(12), 13491355.

Demir, S. (2020). Örgütsel Destek, Örgütsel Özdeşleşme ve İşe Yabancılaşma Arasındaki Yapısal İlişkiler (Osmaniye İli Örneği). Mersin Üniversitesi Eğitim Fakültesi Dergisi, 16(2), 288-300.

Demirel, Y. (2018). Örgütsel güvenin örgütsel bağlılık üzerine etkisi: Tekstil sektörü çalışanlarına yönelik bir araştırma. Yönetim ve Ekonomi. Celal Bayar Üniversitesi İktisadi ve İdari Bilimler Fakültesi Dergisi, 15(2), 179-194.

Demircan, N. ve Ceylan, A. (2003). Örgütsel Güven Kavramı: Nedenleri ve Sonuçları. Celal Bayar Üniversitesi İktisadi ve İdari Bilimler Fakültesi Yönetim ve Ekonomi Dergisi, 10(2), 139-150.

Dinç, E. \& Birincioğlu, N. (2020). Araştırma Görevlilerinin Örgütsel Destek Algıları ve Örgütsel Bağlılıkları Arasındaki İlişkide Lider-Üye Etkileşiminin Aracılık Etkisi. Eskişehir Osmangazi Üniversitesi İ̈BF Dergisi, 15(1), 309 - 330.

Dutton, J. E., J.M. Dukerich ve C.V. Harquail (1994), “Organizational Images and Member Identification", Administrative Science Quarterly, 39(2), 239-263.

Edwards, Martin R. (2005). “Organizational identification: A conceptual and operational review”, International Journal of Management Reviews, 7(4),207-230.

Edwards, Jeffrey R. and Cable, Daniel M. (2009). “The value of value congruence”, Journal of Applied Psychology, 94, 654-677.

Eisenberger, R., Huntington, R., Hutchison, S., \& Sowa, D. (1986). Perceived organizational support. Journal of Applied Psychology, 71,500-507.

Eisenberger, R., Fasolo, P., \& Davis-LaMastro,V. (1990).Perceived organizational support and employee diligence, commitmentand innovation. Journal of Applied Psychology, 75, 51-59.

Eisenberger,R., Armeli, S., Rexwinkel, B., Lynch, P.D.,\&Rhoades,L.(2001). Reciprocation of Perceived Organizational Support. Journal of Applied Psychology, 86, 42-51.

Epitropaki, O.T. \& Martin, R. (2005). The Moderating Role of Individual Differences in the Relation Between Transformational/Transactional Leadership Perceptions and Organizational Identification. The Leadership Quarterly,16,569 - 589.

Eğribayır, D. (2015). The relation between organizational trust, organizational support and organizational commitment. African Journal of Business Management, 9(4),134-156.

Gakovic, Anika ve Lois E. Tetrick (2003), “Perceived Organizational Support and Work Status: A Comparison of The Employment Relationships of Part-Time and Full-Time Employees Attending University Classes", Journal of Organizational Behavior, 24, 649-666.

İplik, E., İplik, F.N. ve Efeoğlu, İ.E. (2014) “Çalışanların Örgütsel Destek Algılarının Örgütsel Vatandaşlık Davranışı Üzerindeki Etkisinde Örgütsel Özdeşleşmenin Rolü”, Uluslararası İktisadi ve İdari İncelemeler Dergisi, 6(12), 109-122.

İşcan, Ö. F. ve U. Sayın (2010). Örgütsel Adalet, İş Tatmini ve Örgütsel Güven Ara- sındaki İlişki”, Atatürk Üniversitesi İktisadi ve İdari Bilimler Dergisi, 24(4), 195-216. 
Kabadayı, M., \& Türkay, O. (2020). Yönetsel Gücün Örgütsel Güven-Performans ve Özdeşleşme Etkileşimi Kapsamındaki Rolü: Bodrum'daki Otel İşletmelerinde Bir Uygulama. Yönetim Bilimleri Dergisi, 18(35), 111-139.

Kaplan, M. Ve Öğ̈̈t, A. (2012). “Algılanan Örgütsel Destek ile Örgütsel Bağlılık Arasındaki İlişkinin Analizi: Otel İşletmelerinde Bir Uygulama” Süleyman Demirel Üniversitesi İktisadi İdari Bilimler Enstitüsü Dergisi, $17,387-401$.

Karabey, C.N. ve İşcan, Ö.F.(2005). “Örgütsel Özdeşleşme, Örgütsel İmaj ve Örgütsel Vatandaşlık Davranış1 İlişkisi Bir Uygulama", Atatürk Üniversitesi İktisadi İdari Bilimler Dergisi, 21(2), 231-241.

Khattak, Mohammed Nisar, Shah, Tazeem Ali and Said, Bahadar (2014). "Significant predictor and outcome of interpersonal trust: Empirical evidence from Pakistan", Business and Management, 6(2),153-168.

Keleş, M., \& Koç H. (2020). Vatanseverlik Değeri ile Çoklu Zekâ Alanları Arasındaki İlişkiyi Belirlemeye Yönelik Bir Araştırma, Uluslararası Sosyal Bilimler Eğitimi Dergisi, 6(1), 33-47

Kerse, G. ve Karabey, C.N. (2017). Algılanan Örgütsel Desteğin Örgütsel Özdeşleşmeye Etkisi: Örgütsel Sinizmin Aracı Rolü. Manas Sosyal Araştırmalar Dergisi, 6(4), 375-398.

Kim, K. Y., Eisenberger, R., ve Baik, K. (2016). Perceived organizational support and affective organizational commitment: Moderating influence of perceived organizational competence. Journal of rganizational Behavior, 37(4), 558-583.

Kurtessis, J. N., Eisenberger, R., Ford, M. T., Buffardi, L. C., Stewart, K. A., ve Adis, C. S. (2017). Perceived organizational support: A metaanalytic evaluation of organizational support theory. Journal of Management, 43(6), 1854-1884.

Loi, R., Hang-Yue N. ve Foley S. (2004), “The Effect Of Professional Identificatıon on Job Attitudes: A Study of Lawyers In Hong Kong", Organizational Analysis, 12( 2), 109-128.

Mael, F.A. ve Blake E.A. (1992). Alumni and Their Alma Mater: A Partial Test of the Reformulated Model of Organizational Identification, Journal of Organizational Behaviour, 13(2), 103- 123.

Matthai, J. (1989). Employee perceptions of trust, satisfaction, and commitment as predictors of turnover intentions in a mental health setting. Unpublished doctoral dissertation, Vanderbilt University.

Mayer R. C., Davis, J. H., \& Schoorman, F. D. (1995). An Integration Model of Organizational Trust, Academy of Management. The Academy of Management Review. 20(3), 709- 734.

Meyer, J. P., Irving, P. G., \& Allen, N. J. (1998). Examination of the combined effects of work values and early work experiences on organizational commitment. Journal of Organizational Behavior, 19, 29 -52.

Meyer, J.P., Stanley, D.J., Herscovitch, L. and Topolnytsky, L. (2002) 'Affective, Continuance, and Normative Commitment to the Organization: A Meta-analysis of Antecedents, Correlates and Consequences', Journal of Vocational Behavior 61,20-52.

Miller, V.D., M. Allen, M.K. Casey ve J.R. Johnson, 2000. “Reconsidering the Organizational Identification Questionnaire", Management Communication Quarterly, 13 (4), 626-658.

Mishra, A.K (1996), Organizational Responses to Crisis: the Role of Trust, Roderick M Kramer ve Rom T.Tyler (Der), Trust in Organizations: Frontiers of Theory and Research, 114-139, sage Publications, London

Moorman, R. H., Blakely, G.L. ve Niehoff, B.P., (1998). “Does Perceived Organizational Support Mediate the Relationship between Procedural Justice and Organizational Citizenship Behavior?", The Academy of Management Journal, 41(3), 351-357.

Naktiyok, S., \& İşcan, Ö.F. (2019). Örgütsel Desteğin Örgütsel Bağlllık Üzerine Etkisinde Örgütsel Güven Algısının Aracı Rolü, İsletme Araştırmaları Dergisi, 11 (2), 1029-1043.

Narang, L. ve Singh, L. (2012). Role of perceived organizational support in the relationship between HR practices and organizational trust. Global Business Review, 13(2), 239-249. 
Nartgün, Ş.S. ve Kalay, M. (2014). Öğretmenlerin Örgütsel Destek, Örgütsel Özdeşleşme İle Örgütsel Sinizm Düzeylerine İlişkin Görüşleri. International Periodical For The Languages, Literature and History of Turkish or Turkic, 9 (2), 1361-1376.

Neves, P., \& Caetano, A. 2006. Social exchange processes in organizational change: The roles of trust and control. Journal of Change Management, 6,351-364

Nyhan, R. C., And H. A. Marlowe. (1997); Development And Psychometric Properties Of The Organizational Trust Inventory, Evaluation Review, 21(5),614-635

O'Reilly, C. 1989. Corporations, culture and commitment: Motivation and social control in organizations. California Management Review, 31(4), 9-25.

Öktem, Ş., Kızıltan, B. ve Öztoprak, M. (2016). Örgütsel Güven İle Örgüt İkliminin Örgütsel Özdeşleşme, İş Tatmini ve İşten Ayrılma Niyeti Üzerine Etkileri: Otel İşletmelerinde Bir Uygulama. Isşletme Araştırmaları Dergisi. 8(4), 162-186.

Özdevecioğlu, Mahmut (2003), “Algılanan Örgütsel Destek ile Örgütsel Bağlılık Arasındaki İlişkilerin Belirlenmesine Yönelik Bir Araştırma", D.E.Ü.İ.I.B.F. Dergisi, 18(2), 113-130.

Özgan, H. (2011). Örgütsel davranış bağlamında öğretmenlerin örgütsel adalet, güven, bağlılık, yönetici değerlendirme ve çatışma yönetimi stratejileri algıları arasındaki ilişkilerin incelenmesi. Kuram ve Uygulamada Ĕ̆itim Bilimleri, 11(1), 229-247.

Özgül, B.,Erkmen,T.,Karaaslan,E.(2020). Algılanan Örgütsel Destek İle Örgütsel Bağlllık İlişkisinde İş-Yaşam Dengesinin Aracılık Rolü Üzerine Bir Araştırma. Busıness \& Management Studıes: An Internatıonal Journal8(5), 4364-4412

Paille, P., and Bourdeau, L. (2010), 'Support, Trust, Satisfaction, Intent to Leave and Citizenship at Organisational Level: A Social Exchange Approach,' International Journal of Organisational Analysis, 18, $41-58$

Parasuraman, S., Greenhaus, J. H., \& Granrose, C. S. (1992). Role stressors, social support, and well-being among two-career couples. Journal of Organizational Behavior, 13, 339-356.

Polat M. ve Meydan C.H. (2011). Örgüt Kültürü Bağlamında Güç Eğilimi ve Örgütsel Bağlllık İlişkisinde Örgütsel Özdeşleşmenin Aracilık Rolü. Atatürk Üniversitesi İktisadi ve İdari Bilimler Dergisi 25(1), 153170.

Porter, L. W., Steers, R. M., Mowday, R. T., \& Boulian, P. V. (1974). Organizational commitment, job satisfaction, and turnover among psychiatric technicians. Journal of applied psychology, 59(5), 603-609.

Rhoades, L., Eisenberger, R. ve Armeli, S. (2001). Affective commitment to the organization: the contribution of perceived organizational support. Journal of Applied Psychology, 86, 825-836.

Rhoades, Linda ve Eisenberger, Robert (2002), "Perceived Organizational Support: A Review of the Literature", Journal of Applied Psychology, 87 (4), 698-714.

Riketta, M. (2005). Organizational identification: A meta-analysis. Journal of Vocational Behavior, 66(2), 358-384.

Rousseau, D. M. (1998). Why workers still identify with organizations. Journal of Organizational Behavior, 19, 217-233.

Sass, J.S. ve D.J. Canary (1991), “Organizational Commitment and Identification: An Examination of Conceptual and Operational Convergence", Western Journal of Speech Communication, 55, 275- 293.

Shanock, L. R., \& Eisenberger, S. (2006). When supervisors feel suported: Relationships with subordinates' perceived supervisor support, perceived organizational support, and performance. Journal of Applied Psychology, 91(3), 689-695.

Settoon, R. P., Bennett, N. ve Liden, R.C., (1996). “Social Exchange in Organizations: Perceived Organizational Support, Leader-Member Exchange, and Employee Reciprocity", Journal of Applied Psychology,81(3), 219-227. 
Shore, L. M ve Wayne S. J., (1993). “Commitment and Employee Behavior: Comparison of Affective Commitment and Continuance Commitment With Perceived Organizational Support", Journal of Applied Psychology, 78( 5), 774-780.

Sökmen, A.; Ekmekçioğlu, E. B.; Çelik, K. (2015). “Alg1lanan örgütsel destek, örgütsel özdeşleşme ve yönetici etik davranışı ilişkisi: araştırma görevlilerine yönelik araştırma", İşletme Araştırmaları Dergisi, 7(1), 125144.

Sökmen, A., \& Bıyık, Y. (2016). Örgütsel bağlılık, örgütsel özdeşleşme, kişi-örgüt uyumu ve iş tatmini ilişkisi: Bilişim uzmanlarına yönelik bir araştırma. International Journal of Informatics Technologies, 9(2), 221-227.

Sökmen, A. (2019). Örgütsel Özdeşleşme, Örgütsel Bağlllık ve İş Tatmini İlişkisi: Otel İşletmelerinde Bir Araştırma. Journal of Tourism and Gastronomy Studies, 7(2), 980- 990.

Tan, H ve C.S. Tan, (2000) "Towards the Differentiation of Trust in Supervisor and Trust in Organization", Genetic, Social and General Psychology Monographs, 126(2), 241-260.

Taşdan, M., ve Yalçın, T. (2010). İlköğretim okulu öğretmenlerinin algıladıkları sosyal destek ile örgütsel güven düzeyleri arasındaki ilişki düzeyi. Kuram ve Uygulamada Ĕ̆itim Bilimleri, 10(4), 2569- 2620.

Taşkın, F. Ve R. Dilek (2010), “Örgütsel Güven ve Örgütsel Bağlılık Üzerine Bir Alan Araştırması”, Organizasyon ve Yönetim Bilimleri Dergisi, 2 (1), 37-46.

Toklu T.A.(2016). Çalışanlarda İş Sağhlğı ve Güvenliği Uygulamalarının Örgütsel Bă̆hllık, İşe Yabancılaşma ve İş Performansina Olan Etkisinin İncelenmesi, (Yayınlanmamış Doktora Tezi), Gebze Teknik Üniversitesi, Kocaeli

Tokgöz, E., Seymen, O.A.(2013), “Örgütsel Güven, Örgütsel Özdeşleşme ve Örgütsel Vatandaşlık Davranış1 Arasındaki İlişki", Öneri Dergisi, 10(39), 61-76.

Toprak, L.S., Şentürk, F.K. ve Kılıç, G. (2017). Yöneticilerin çatışma yönetme yöntemleri ile yöneticiye duyulan güven arasındaki ilişki: Afyonkarahisar'daki beş yıldızlı otel işletmelerinde bir araştırma. İşletme Bilimi Dergisi (JOBS), 5(2), 105-133.

Tumwesigye, G. (2010). “The Relationship Between Percieved Organizational Support and Turnover Intentions In A Developing Country: The Mediating Role of Organizational Commitment", African Journal of Business Management, 4(6), 942-952

Turunç, Ömer \& Çelik, Mazlum. (2010). Algılanan Örgütsel Desteğin Çalışanların İşAile, Aile-İş Çatışması, Örgütsel Özdeşleşme ve İşten Ayrılma Niyetine Etkisi: Savunma Sektöründe Bir Araştırma. Atatürk Üniversitesi Sosyal Bilimler Enstitüsü Dergisi, 14 (1),209 - 232.

Tüzün, İ.K.; (2007), “Güven, Örgütsel Güven Ve Güven Modelleri”, Karamanoğlu Mehmetbey Üniversitesi İktisadi Ve İdari Bilimler Fakültesi Dergisi,93-118.

Tyler, T. R. ve S.L. Blader (2001), "Identity and Cooperative Behavior in Groups", Group Processes \& Intergroup Relations, 4(3), 207-226.

Ural, A. ve Kılıç, İ. (2018) Bilimsel Araştırma Süreci ve Spss ile Veri Analizi, (5.Baskı). Ankara: Detay Yayıncılık.

Uzun, T. (2018). Öğretmenlerin algıladığı örgütsel destek ile örgütsel özdeşleşme ve işten ayrılma niyeti arasındaki ılişki: Örgütsel güvenin aracı rolü. Karadeniz Sosyal Bilimler Dergisi, 10(18), 133-155.

Van Knippenberg, D., \& Sleebos, E. (2006). Organizational identification versus organizational commitment: self-definition, social exchange, and job attitudes.Journal of Organizational Behavior, 27(5), 571-584.

Yoon, J. and Thye, S. R. (2002). "A dual Process Model of Organizational Commitment". Work and Occupations, 29 (1), 97-12 